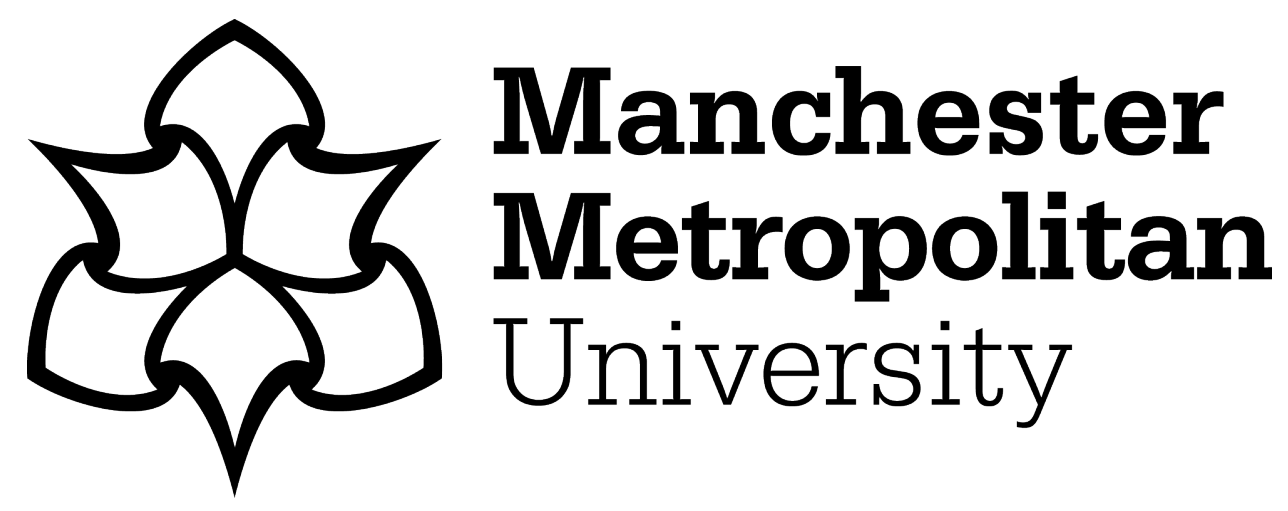

Robertson, James ORCID logoORCID: https://orcid.org/0000-0002-13157950 (2020) Choreographing the Liturgy : Exploring continuity, change and the liturgy in the ecclesiastical buildings of Gillespie, Kidd \& Coia. The Innes Review, 71 (2). pp. 237-269. ISSN 0020-157X

Downloaded from: https://e-space.mmu.ac.uk/626336/

Version: Accepted Version

Publisher: Edinburgh University Press

DOI: https://doi.org/10.3366/inr.2020.0267

Please cite the published version 


\title{
Choreographing the Liturgy
}

Exploring continuity, change and the liturgy in the ecclesiastical buildings of Gillespie, Kidd \& Coia

\begin{abstract}
Architectural responses to the liturgical changes of the twentieth century, and in particular the responses of the renowned architectural practice of Gillespie, Kidd \& Coia (1927-87), have been widely discussed; the latter especially in respect of their dramatic and sometimes enigmatic contributions to post-war ecclesiastical design in Britain. But this concern is predicated on the chronological separation of a body of work, and existing study on this practice tends to reinforce the notion of change within the life of the firm; changes in their design approach from 'traditional' to 'modern', often linked to changes in staffing; and architectural responses to changes in the liturgy. However, in the midst of this changing landscape of church design, modernism and liturgy, is the less studied concept of continuity between Gillespie, Kidd \& Coia's inter and post-war work, and its engagement with a liturgy undergoing modification. Indeed, the ecclesiastical schemes of the inter and early post-war periods have been less often referred to in terms of their ability to command a paradigm shift in the firm's work. However, viewed in their entirety, the practice's scheme designs demonstrate a fascinating pluralistic attitude to design concept and vocabulary; the transmutability of their ideas their currency in spatial, sectional and experiential matters. This article therefore includes continuity as well as change in analysis of churches from across the firm's lifespan, viewing their rich and varied compositions as a complete body of internationally significant work.
\end{abstract}

Fig. 1 (Above Left) St. Anne's, Dennistoun, (Above Middle) Roman Catholic Chaplaincy, Turnbull Hall, University of Glasgow, (Above Right) St. Martin's, Castlemilk, (Below Left) St. Margaret's, Clydebank, (Below Right) St. Columba’s, East Kilbride

\section{Introduction}


This is a study of a process of architectural analysis on Gillespie, Kidd \& Coia, a practice often famed for their original architectural approach, especially for longstanding clients such as the Catholic Archdiocese of Glasgow. ${ }^{1}$ It is primarily concerned with the results of their approach over many years; of the effects or trends apparent in their work as an oeuvre, rather than with their initial architectural intentions. It builds on the work of other scholars by discussing the firm's work within the context of the twentieth century's rather fluid liturgical landscape, but also suggests an alternative method of reading their ecclesiastical architecture that is based not only on difference within their work, but also on its interconnections.

Since its closure in the mid-1980s, a number of authors have contributed to our knowledge of this practice. In 1986, Robert Rogerson (1917-2007) wrote of Jack Coia in the eponymous title charting his life and work, as the practice drew to a close, and while the death of Coia was still a recent memory. ${ }^{2}$ A decade later, Diane Watters, writing for the Royal Commission on the Ancient and Historical Monuments of Scotland (RCAHMS), focused on the creation and subsequent functional and physical disintegration of one of the practice's best known buildings, St Peter's Seminary, Cardross. ${ }^{3}$ This followed DOCOMOMO's highlighting of the complex as a significant example of modern architecture, a photographic survey by RCAHMS in light of proposals for its demolition, and a cataloguing of the scheme drawings at the Mackintosh School of Architecture. ${ }^{4}$ Almost a decade after that, in 2005 Robert Proctor published his important article, Churches for a Changing Liturgy: Gillespie, Kidd \& Coia and the Second Vatican Council, a synopsis of the way in which Gillespie, Kidd \& Coia responded to religious tradition, the Liturgical Movement, architectural Modernism, and the revised Liturgy. ${ }^{5}$ Then in 2007, a collaboration between The Lighthouse: Scotland's Centre for Architecture, Design and the City; The Glasgow School of Art; and RCAHMS; produced an exhibition and publication that demonstrated the firm's architectural output from 1956-1987. ${ }^{6}$ This was accompanied by the cataloguing of the office archives, originally gifted to the Glasgow School of Art by

\footnotetext{
1 Although most of the practice's churches were designed for Catholic parishes, they were not the exclusive ecclesiastical client: towards the end of the practice, Gillespie, Kidd \& Coia accepted a Lutheran commission, St Columba’s, East Kilbride.

${ }^{2}$ Rogerson had initially approached Coia with idea of a book in 1978; see Robert W. K. C. Rogerson, Jack Coia: His Life and Work (Glasgow, 1986), 'About the author'.

${ }^{3}$ Diane Watters, Cardross Seminary: Gillespie, Kidd \& Coia and the Architecture of Postwar Catholicism (Edinburgh, 1997).

${ }^{4}$ Ibid., 4.

${ }^{5}$ Robert Proctor, 'Churches for a Changing Liturgy’ In Architectural History (2005), Vol 48, $291-322$.

${ }^{6}$ Gillespie, Kidd \& Coia Architecture 1956-1987, ed. Johnny Rodger (Glasgow, 2007), 255.
} 
longstanding practice members, Andy MacMillan (1928-2014) and Isi Metzstein (1928-2012) in 2001. ${ }^{7}$ Proctor's more recent book, Building the Modern Church: Roman Catholic Church Architecture in Britain, 1955-1975 (2014), gives, apart from myriad examples of ecclesiastical practices including Gillespie, Kidd \& Coia, a thorough sense of the relationship of church architects to their clients in a period of post-war architectural and liturgical metamorphosis. ${ }^{8}$ In addition, Watters' publication, St Peters, Cardross: Birth, Death and Renewal (2016), offers a further sense of the context in which Gillespie, Kidd \& Coia practiced in addition to their Seminary's (now precarious) future. ${ }^{9}$

A recurrent theme of much of this scholarly study distinguishes the architecturally stimulating later phase from the preceding era by a perceived change in design attitude following the building of St Paul's, Glenrothes (1956-58). Proctor's 2005 work recognises this whilst making a key contribution to the contextualisation of Gillespie, Kidd \& Coia's churches in response to the Liturgy. He draws on selected examples of the practice's ecclesiastical work, mainly from the mid-1950s onwards, grouped under common space organisational themes, in order to do this. The article's central concern appears to be on the reconciliation of the modernity (or otherwise) of Gillespie, Kidd \& Coia's post-war churches in relation to liturgical change. The work discussed in the present article extends some of those observations and foci to include the firm's entire oeuvre of parish churches and other ecclesiastical works, and applies further analytical criteria to each building. The aim was to try to put aside a priori expectations of design attribution, style, chronological separation, and the relationship of the firm's postwar churches to liturgical prescriptions, and instead to examine the spatialisation of the liturgy through continuity of practice, and church design changes or similarities viewed through the same lens, and from an architect's perspective.

\section{Context}

The work of Gillespie, Kidd \& Coia can be set against Clifford Williamson's explanation of conscious institutional renewal of the Catholic community in Scotland between the end of the First World War and the close of the Second Vatican Council in $1965 .{ }^{10}$ This renewal related to various areas that affected Scottish Catholic ecclesial life, including piety, politics, and

\footnotetext{
${ }^{7}$ Ibid., $255-6$

${ }^{8}$ Robert Proctor, Building the Modern Church: Roman Catholic Church Architecture in Britain, 1955 to 1975 (Farnham, 2014).

${ }^{9}$ Diane Watters, St Peter's, Cardross: Birth, Death and Renewal (Edinburgh, 2016).

${ }^{10}$ Clifford Williamson, The History of Catholic Intellectual Life in Scotland, 1918-1965 (London, 2016$), 1$.
} 
national identity, and as Williamson states, 'no single grand project' was proposed for the reassertion of the faith in Scotland, but instead it was promoted by a mixture of methods and organisations that sought to reframe Scottish Catholic identity. ${ }^{11}$ The linked actions of the Catholic community in Scotland were not an isolated movement, but rather one that was panEuropean; even worldwide, which had as its aim the countering of the prominent secular ideologies of liberalism, socialism and communism. ${ }^{12}$

As well as an increase in Catholic presence in Scotland, a parallel movement involving renewal of the Roman Catholic liturgy unfolded over the course of the twentieth century in the Liturgical Movement. 'The liturgy' is encapsulated in the collective activity of Christians as a 'worshipping community', and as Charles Davis asserts, the church building is a place that facilitates this activity. ${ }^{13}$ The Roman liturgy in its diverse expressions, involves gesture, movement and routine, and affects the disposition of certain spaces or fixtures within a church as they relate to various aspects of the rite. ${ }^{14}$ It can be argued that the church building is required to mediate between the functional or physical, and the experiential or ritual aspects of a worshipping community.

The liturgy manifests itself according to its actions in the dimensional, directional, and volumetric arrangements of the spaces around it. The clarity of the relationship between space and function varied historically. Among early Christian communities, spatial organisation reflected the active nature of the liturgy most lucidly. Churches tended to consist of a simple, clearly defined space - often oblong in layout, and with a separate, clearly delineated sanctuary. The altar was the liturgical focus of the space and may have addressed a single hall-like space or a space with a room to each side as well, or transepts. There was a distinct relationship between the presiding celebrant and the laity, with good lines of sight and audibility. ${ }^{15}$

Medieval churches, to some extent, diluted the legibility of the early layouts, instead contriving space with many additional elements, particularly between the altar and the people,

\footnotetext{
${ }^{11}$ Ibid., 1.

12 Ibid., 1.

${ }^{13}$ Charles Davis, 'Church architecture and the liturgy', in Towards a Church Architecture, ed. Peter Hammond (London, 1962), 107-27, at 107.

${ }^{14}$ See Aimé Martimort, 'Liturgical signs', in The Church at Prayer Volume 1: Principles of the Liturgy, ed. Aimé Martimort (Collegeville, 1983), 173-225, at 178-210.

15 Ibid., 204.
} 
incorporating choirs, clergy and associated seating, and rood screens obscuring the altar, thereby weakening the central premise of the liturgy as a communal act of celebration. ${ }^{16}$

In contrast, the spirit of the Counter-Reformation could be found in the singular spaces of Jesuit churches, such as the Church of Il Gesù in Rome (1568-75), with clear sight-lines to the high altar and pulpit, and side-chapels for individual use clearly connected to the principal liturgical space. ${ }^{17}$ In the nineteenth century, the building of new churches after Catholic emancipation ranged from the relatively anonymous to the outright flamboyant, and a return to historical models, such as the medieval, through the ideas of architects such as A.W.N. Pugin. ${ }^{18}$

The Liturgical Movement gained credence in the wake of the reforming nature of Pius X (1903-14), ${ }^{19}$ a Pope who condemned Modernism within the Church $^{20}$ and promoted the traditional liturgy, where connection with the faithful had been obscured. The reforms concerned, among other changes, more active participation of the congregation, given that the 'celebration' that this involved lay at the root of what it meant to be Christian. ${ }^{21}$ Following the reforms of Pius X, the emphasis on 'active participation' was furthered enthusiastically in Belgium from 1909, and in France shortly after the First World War, where the liturgy was made accessible to the young through the use of the dialogue Mass. In Germanythe theology of Romano Guardini (1885-1968) and Dom Odo Casel (1886-1948) was particularly significant. ${ }^{22}$ The Liturgical Movement (and long before Gillespie, Kidd \& Coia) sowed the seeds that would blossom through the resolutions of the Second Vatican Council, some forty years later.

In architectural theory, according to Rudolf Stegers, a 'rift' had developed since the pursuit of Modernism, between a genuine religious experience and its aesthetic, built manifestation. ${ }^{23}$ This view is highlighted in layout and other design terms by the views of the contributors of

\footnotetext{
${ }^{16}$ Ibid., 204-5.

${ }^{17}$ Martin Purdy, Churches and Chapels: A Design Development Guide (Oxford, 1991), 13.

${ }^{18} \mathrm{Ibid}$. However, Watters describes some late nineteenth century examples of the successor firm of Pugin \& Pugin as 'hall-like'; evocative of a 'Continental Gesu tradition', within the context of Glasgow and environs. See Watters, Cardross Seminary, p. 14.

${ }^{19}$ Pierre Jounel, 'From the Council of Trent to Vatican Council II', in The Church at Prayer, ed. Martimort, 6384 , at $73-4$.

${ }^{20}$ See papal writings such as Pascendi Dominici Gregis: Pope Pius X (1907) Pascendi Dominici Gregis. The Holy See, online at http://www.vatican.va/content/pius-X/en/encyclicals/documents/hf_p$\mathrm{x}$ enc 19070908 pascendi-dominici-gregis.html (accesed 20th July 2020)

${ }^{21}$ Pierre Jounel, 'From the Council of Trent to Vatican Council II', in The Church at Prayer, ed. Martimort, 6384 , at $73-4$.

${ }^{22}$ Ibid., 74-5.

${ }^{23}$ Rudolf Stegers, Sacred Buildings: A Design Manual (Basel, 2008), 9.
} 
Towards a Church Architecture, a publication edited by the influential Anglican, Peter Hammond, arising from his involvement with the New Churches Research Group (NCRG). ${ }^{24}$ In his criticism of modern churches, Hammond focuses on the need for church design to be based on genuine social and liturgical principles and not merely on aesthetic contrivances. This recognition of the fundamental reason for building a church is illustrated in the work of Rudolf Schwarz (1897-1961), whose early schemes are based on the precept that a church is primarily for housing a community, placing an emphasis on the liturgical needs of the people and not on the fabric of the building in which they were to be housed.

In the UK only a handful of churches challenged the status quo in direct spatial terms borne of grass-roots user and liturgical principles, with Proctor noting less familiarity with the Liturgical Movement prior to the 1950s, with examples such as Eric Gill and J. H. LangtryLangton's St Peter, Gorleston-on-Sea (opened 1939) and Our Lady and the First Martyrs, Bradford (1935), with their altar-focused plans, and the diagrammatic 'Dream-Church' of Mgr. J. D. Crichton (1907-2001) in 1942. ${ }^{25}$ Although Crichton's idea was unbuilt, his thinking was significant in the encouragement of the Liturgical Movement, using as a means of dissemination his 20 year editorship (1952-72) of Music and Liturgy, the journal of the Society of Saint Gregory - an organisation whose very foundations were formed on the beliefs of Pius $\mathrm{X} .^{26}$

In Scotland, Reginald Fairlie's unusually shaped octagonal Church of the Sacred Heart at Cowie in Stirlingshire (1937) suggested an outline, alternative, future plan type, notwithstanding its more conventionally disposed hierarchical focus; the altar being placed within an apse attached to one of the facets of the octagon. ${ }^{27}$ However, despite Gillespie, Kidd \& Coia's equally and consistently original material and volumetric concepts seen from the start, as Proctor assesses, even the majority of the firm's post-war designs were functionally only partially literate with a liturgy on the move, due mainly to their adherence to traditionally set briefs. $^{28}$

\section{Methodology and analysis of this study}

\footnotetext{
${ }^{24}$ Robert Proctor, Building the Modern Church (Farnham, 2014), 133-34.

${ }^{25}$ Ibid., 142-5.

${ }^{26}$ Society of Saint Gregory, 'Monsignor James Crichton', and 'A Brief History of the Society', Society of Saint Gregory, online at https://www.ssg.org.uk/about-us/history-of-ssg/ (accessed $1^{\text {st }}$ April 2020).

${ }^{27}$ Patrick Nuttgens, Reginald Fairlie 1883-1952 A Scottish Architect (Edinburgh, 1959).

${ }^{28}$ Robert Proctor, 'Churches for a Changing Liturgy' In Architectural History (2005), Vol 48, 291-322, at 318.
} 
In the research that preceded this article, the outputs of Gillespie, Kidd \& Coia were evaluated as a single practice through a series of experiential and technical filters, using text and diagrams to analyse their parish churches, chapels and oratories (see Appendix). Furthermore, a pilot study on selected buildings was subsequently undertaken using the littletried techniqueD of 3D laser scanning, producing working two and three-dimensional images. This recorded planning, sectional, volumetric and lighting perspectives not always possible to see with the human eye. It also revealed graphical data about less discussed schemes such as the Archbishop's Oratory at Park Circus, an insertion into an existing building, and St. Columba's Lutheran Church, East Kilbride; the practice's final, and only church commission not undertaken for their Roman Catholic clients. Apart from implicit heritage value, this technology has the specific potential to create an architectural repository of the firm's complete work to track design continuity and change. This article focuses on a small number of the firm's nearly forty religious commissions, with each parish church, chapel or oratory being analysed through the following criteria: liturgy, plan, section (both its relationship to light and to structure), volume (tectonic arrangement and massing), and materials. Of these themes, liturgy, by virtue of its social, functional and symbolic basis, acts as an umbrella to the other themes, which are primarily concerned with architectural principles or techniques.

\section{Theme 1: Liturgy}

Liturgy, although fundamentally connected to all the other themes, is concerned with the user's journey up to and through the building, as well as the specific spatial arrangements and more symbolic qualities, such as the placement of sacred objects within it, and ambient effects on the space. It is also an important factor in establishing liturgical prescription at a given point. The rubrics of the Mass, however, were constant. For example the Eucharistic rite remained a focal point in both the traditional and new forms of the Roman Catholic liturgy, as did baptism. ${ }^{29}$ In The Church Incarnate (1938), Rudolf Schwarz spatialised changing liturgical ideas in a novel graphical way at a time when many churches were essentially still traditional in liturgical arrangement. His diagrammatic spatial schemata were representative of fundamental relationships between the worshipping community and God. This followed his seminal Corpus Christi church at Aachen (1930), which eschewed architectural and liturgical

\footnotetext{
${ }^{29}$ Hammond was criticised for appearing to emphasise only the Eucharistic rite in Liturgy and Architecture (London, 1960); see Proctor, Building the Modern Church, 139.
} 
superfluity and clarified liturgical relationships in a plan that connected the altar visually and physically with worshippers. ${ }^{30}$

\section{Parish churches, chapels and oratories designed by Gillespie, Kidd \& Coia}

\section{DATE}

St. Anne, Dennistoun

St. Patrick, Greenock

St. Columbkille, Rutherglen

St. Columba, Woodside

St. Peter in Chains, Ardrossan

Roman Catholic Pavilion, Bellahouston Park 1938

Holy Family, Port Glasgow

St. Joseph, Greenock

St. Kevin, Bargeddie

Archbishop's Oratory, Park Circus, Glasgow

St. Eunan, Clydebank

St. Matthew, Bishopbriggs

St. David, Plains

St. Laurence, Greenock

St. Michael, Dumbarton

St. Andrew, Airdrie

Ss. Peter and Paul, Arrochar

Roman Catholic Chaplaincy, Turnbull Hall, 1955

University of Glasgow

St. Maria Goretti, Cranhill

St. Joachim, Carmyle

St. Paul, Glenrothes

St. Kessog, Balloch

St. Paul the Apostle, Shettleston

St. Vincent de Paul, Thornliebank

St. Charles Borromeo, Kelvinside

St. Mary of the Angels, Camelon

\section{CHURCH}

1931-33

1934-35

$1934-40$

1937-38

1938

1946-59

1947-50

1947-50

1948-55

1950

1950

1950

1951-54

1952-54

1953

1953

1955

1956

1956-58

1957

1959

1959

1959

1960-61

\footnotetext{
${ }^{30}$ Mark Torgerson An Architecture of Immanence: Architecture for Worship and Ministry Today (2007), 109.
} 
St. Martin, Castlemilk

St. Mary, Borrowstouness

St. Bride, East Kilbride

St. Patrick, Kilsyth

St. Joseph, Faifley

Sacred Heart, Cumbernauld

Our Lady of Good Counsel, Dennistoun

St. Benedict, Easterhouse

St. Benedict, Drumchapel

St. Margaret, Clydebank

St. Columba, East Kilbride

St Anne's, Dennistoun (1933), St Patrick's, Greenock (1934-35), St Columbkille's, Rutherglen (1934-40), and St Columba's, Woodside (1937-38) all observe the traditional hierarchy of the laity facing the sanctuary and altar in a single block, in the manner of CounterReformation churches such as Il Gesù, and re-ordered churches such as Sta. Maria in Ara Coeli, rather than medieval layouts where a choir sometimes interrupted the connection between the two. Gillespie, Kidd \& Coia's early examples were supported by Pius X's direction on the accommodation of lay choirs in galleries, the negation of aisle seating for better visual connection with the altar, and generously proportioned sanctuaries to accommodate greater numbers of people kneeling at the altar rail during communion. ${ }^{31}$ These liturgical concessions were given strong architectural expression in the cave-like barrel-vaulted volume of St Anne's, made possible by the minimisation of aisles, and in the strikingly tall, semi-autonomous entrance volumes of St Columbkille's and St Columba's, which house choir galleries over a narthex. The ceremonies of the Mass of the Roman Rite and their relationship to space was well illustrated in 1938 when St Peter-in-Chains, Ardrossan, was solemnly opened by Archbishop Donald Mackintosh (1876-1943) in a ceremony carried out in the elaborate context of a Pontifical High Mass. ${ }^{32}$

\footnotetext{
${ }^{31}$ Robert Proctor, Building the Modern Church (Farnham, 2014), 142.

32 The Church of St Peter in Chains, Ardrossan, 'Opening Ceremony 2 October 1938', The Church of St Peter in Chains, Ardrossan (2005), on line at http://www.saintpeterinchains.net/ (accessed 20 February 2020).
} 
While Schwarz's writing could not have had any direct influence on Gillespie, Kidd \& Coia's work in the 1930s, the processional model that he discussed in his Fourth Plan reflected a common liturgical diagram with some of those early churches; the 'arching tunnel', expressed in the plastered barrel vault of St Anne's, and the Gothic framework of St Columba's [2]. ${ }^{33}$ As Schwarz suggests in his text, these are perhaps linked to a more fundamental concept of sacred procession found in the Early Christian basilica and the 'all-embracing' shelter of the Gothic church. ${ }^{34}$

Fig. 2 Rudolf Schwarz: (left) 'The fourth plan: Sacred journey: The way' and (middle) 'The fourth plan: Sacred journey: The way': vaulting, and (right) 'The third plan: Sacred parting: The chalice of light'

Similarly, it could be argued that the overhead light described in Schwarz's Third Plan is paralleled with the oculus retained in the Archbishop's Oratory, Glasgow (1948-55), and then designed for the side chapels of the churches of St Laurence, Greenock (1951-54) and St Michael, Dumbarton (1952-54) [2]. The simple oculi of Roman mausolea and their illusionistic and expressive use in the domes of Byzantine and Baroque churches suggest a possible precedent. ${ }^{35}$

Despite any apparent similarities with the combinatory ideas of liturgy and architecture put forward by Schwarz, in the main, Gillespie, Kidd \& Coia's churches - particularly those built before the Second Vatican Council - more likely shared much older fundamental notions of liturgical experience and space. Aesthetically they did not share the same pared-back clarity of expression as Schwarz's Corpus Christi, or St Anna, Düren (1956), with the exception of the Catholic Pavilion at the Glasgow Empire Exhibition of 1938, which began to approach something of the combined functionality and spirituality in architecture discussed by Schwarz. At the time of its building, the historian (and Catholic), Peter Anson, recognised its potential as a vehicle for modern ecclesiastical architecture in Scotland. ${ }^{36}$

From the mid-1960s, more attempts at centralisation of the laity around the altar was evident in the churches of St Joseph, Faifley (1964), St Patrick, Kilsyth (1964), Sacred Heart, Cumbernauld (1964), Our Lady of Good Counsel, Dennistoun (1965), St Benedict, Easterhouse

\footnotetext{
${ }^{33}$ Rudolf Schwarz, Vom bau de kirche (Heidelberg, 1938); transl. Cynthia Harris, The Church Incarnate: The Sacred Function of Christian Architecture (Chicago, 1958), 136.

${ }^{34}$ Rudolf Schwarz, Vom bau de kirche, transl. Harris, 135-9.

${ }^{35}$ Ibid., 96-7.

${ }^{36}$ Diane Watters, Cardross Seminary: Gillespie, Kidd \& Coia and the Architecture of Postwar Catholicism (Edinburgh, 1997), 23.
} 
(1965), St Benedict, Drumchapel (1965-67), St. Margaret, Clydebank (1972) and St Columba, East Kilbride (1979), ${ }^{37}$ recalling derivatives of Schwarz's earlier notions of centralisation in such gestures as the 'Open Ring' of his Second Plan. ${ }^{38}$ Proctor concedes that whilst some of these buildings acknowledge the Liturgical Movement despite their still traditional briefs, only one, St. Margaret's, responded to the 'fully conscious, and active participation, 39 of the laity in the Mass, having been built after the implementation of the new liturgy. ${ }^{40}$ Duncan Stroik, however, has argued that the Second Vatican Council did not actually deem an entirely new form of ecclesiastical architecture necessary to serve the new liturgy. ${ }^{41}$ Randall Smith, meanwhile, writing in the same issue of Sacred Architecture as Stroik, pithily illustrated a common misconception in 'modern' church architecture: namely, the confusion of the functional 'ideas' of architectural modernism with a renewed idea of the liturgy. ${ }^{42}$

Through their designs, Gillespie, Kidd \& Coia facilitated the two principal sacramental liturgical rites - the Eucharistic rite, centred on the altar contained within a sanctuary, and the baptismal rite, centred around the font - in several ways. Sanctuaries are either expressed as a predominantly wide, shallow space, articulated from the nave, as a space at the termination of the nave that is implied by the subtle indentation of the side wall, or completely contained and incorporated within the main space, and defined only with fixtures or lighting. The different responses are not wholly representative of church chronology, although the later buildings following the Second Vatican Council tend to rely on the incorporated method, from St Bride's until the final commissions. For example, the expressed sanctuary is first seen at St Anne's, and continues into the early 1960s, even in the experimental and unconventional forms of St Paul's, Glenrothes, St. Martin's, Castlemilk (1961), and St Mary's, Bo'ness (1962). The intermediate, indented-wall method first appeared in the post-war schemes with churches such as Holy Family, Greenock (1946-59), where the south side of the building indents the bay closest to the sanctuary to define it liturgically. Similarly, at St Matthew, Bishopbriggs (1950), the sanctuary is defined only by being very slightly inset from the main body of the nave, and by a dais of

\footnotetext{
${ }^{37}$ St. Columba's was designed for a non-Catholic liturgy, but was the firm's final church building.

${ }^{38}$ Rudolf Schwarz, Vom bau de kirche, transl. Harris, 69

$39{ }^{39}$ Constitution on the Sacred Liturgy, Sacrosanctum Concilium (Vatican, 1963), §14; official English translation, on line at https://www.vatican.va/archive/hist councils/ii vatican council/documents/vatii const 19631204 sacrosanctum-concilium en.html (accessed 20 February 2020).

${ }^{40}$ Robert Proctor, 'Churches for a Changing Liturgy' In Architectural History (2005), Vol 48, 291-322, at 315.

${ }^{41}$ Duncan Stroik, 'Forma extraordinaria', Sacred Architecture 13 (2007), 2.

${ }^{42}$ Randall Smith, 'Don't blame Vatican II; modernism and modern Catholic church architecture', Sacred Architecture 13 (2007), 12-18.
} 
three white marble steps surmounted by an altar. Above, the ceiling level and treatment does not change, but although the baldacchino is compactly flattened to the ceiling, its chamfered timber profile acts as an effective liturgical marker within the sanctuary.

The pre-Vatican II placement of baptisteries within the church itself supplanted a prior tradition of standalone buildings, and was often close to the church entrance. ${ }^{43}$ In addition to this, canonical legislation began to refer to baptismal fonts rather than baptisteries, and fonts - then more peripatetic - could be placed in the sanctuary, harmonising with increasing opportunity for 'community participation'. ${ }^{44}$ Martimort explains that the problem with a sanctuary location was that it was at odds with the concept of Christians revering their place of baptism. Following the Second Vatican Council, in 1969, the Novus Ordo allowed both for the sanctuary-based font and the more traditional conception of a baptistery as a separate entity, 'in a chapel either inside or outside the church or in some part of the church easily seen by the faithful' ${ }^{45}$ In Gillespie, Kidd \& Coia's churches, the dominance and position of the baptismal font is varied, ranging from defined zones adjoining the principal building volume, in the case of St Anne's, to its placing in a lateral bay at St Columbkille's. This placement anticipates the near total separation of the baptistery that would occur at St Charles Borromeo, Kelvinside, by 1959, and St Mary's three years later. In between were attempts to integrate a baptistery into a sequential experience, beginning with post-war churches such as St Matthew's, St Eunan's, Clydebank (1950), and St Michael's, Dumbarton, near the entrance to the church, to the precise promenade-like staging of St Paul's, Glenrothes and St Bride's, which acknowledge the renewed interest in the baptismal rite, by liturgical scholars, in the post-war years. ${ }^{46}$ At St Michael's, although now altered, the baptistery was originally in the space now occupied by the library. The sense of dramatic procession is still palpable though, with ascent from Cardross Road to the south entrance, through the large screen of glass and into the nave; then a pivotpoint about an east-west axis, where the baptistery is situated to the west, lit by a large, shallowly pedimented window at high level.

As may be expected, the devotional element of the Stations of the Cross allows procession around the periphery of the church, as at St Anne's and the Archbishop's Oratory. At the Roman

\footnotetext{
${ }^{43}$ Aimé Martimort, 'Liturgical Signs', in The Church at Prayer, ed. Martimort, 173-225, at 210.

${ }^{44}$ Ibid.

45 Praenotanda 25 (DOL 294 no. 2274) in Aimé Martimort, 'Liturgical Signs', in The Church at Prayer, ed. Martimort, 173-225, at 210.

${ }^{46}$ Robert Proctor, Building the Modern Church, 195.
} 
Catholic Chaplaincy, Glasgow (1955), however, they are ranged along one side of the nave only, given the access opening in the west wall. Other churches demonstrate remarkable integration of the Stations of the Cross with the building fabric itself; at St Martin's, Castlemilk, the sculpted panels form part of the angled window reveals, but although interesting, as Proctor asserts, their separation from the canonical wooden crosses, makes them seem somewhat peripheral. $^{47}$

\section{Theme 2: Plan}

The study of building plan highlights development or change in physical form, layout and programmatic intent. We can note in the early phase the continuation of somewhat traditional planning models, but supplemented from the 1950s with a more experimental and expressive approach to plan form.

Gillespie, Kidd \& Coia's churches describe three main plan types; those that are based on a straight processional axis, those that employ the concept of the promenade architecturale as demonstrated by Le Corbusier, and those that are based on a form of centralisation. ${ }^{48}$ The first type is usually basilican, with some variation through the incorporation of short transepts, rendering layouts such as St. Anne's loosely cruciform, and other secondary spaces off the main axis and relates to the traditional form of the liturgy, while also being able to respond to changes in thinking that were part of the Liturgical Movement. Many of the firm's churches were underpinned by a longitudinal axis like the early Christian basilicas, with the earlier schemes (St Anne's, St Patrick's, St Columbkille's, St Columba's and St Peter in Chains) tending towards a centrally positioned axis generally with symmetrically organised accommodation around it. These buildings display a traditional, staged approach, which requires visitors to pass through a distinctively articulated intermediate zone or narthex, housing a choir gallery, and sometimes incorporating a significantly stepped level change (for example at St Anne's and St Patrick's), before proceeding on axis into the nave and towards the altar. The largest space, before that of the sanctuary, was organised in numerous ways, either split into hierarchical groupings or unified into a single zone. The second type, also strongly ceremonial, is based on the concept of spatial revelation and discovery. Routes that began externally and ended at the altar were cast around a range of plan forms including wedgeshapes, rectangular boxes and cubes. The theory of the architectural promenade churches is

\footnotetext{
${ }^{47}$ Ibid., 233.

${ }^{48}$ As Proctor notes that Gillespie, Kidd \& Coia's designs were not wholly centralised, in the way that Liverpool Metropolitan Cathedral is, for example. See Robert Proctor, Building the Modern Church, 310-1.
} 
well documented in Gillespie, Kidd \& Coia's work, with some of the most significant examples being found at St Paul's, Glenrothes, St Bride's, St Patrick's, and Our Lady of Good Counsel. ${ }^{49}$ St Martin's, St Mary's, and St Benedict's, Drumchapel, however, appear to exploit the experience too. For the third type, centralised plans in themselves were not a new concept in the spatial arrangement of a church but interrupted the linear sequencing of the previous examples and also changed the relationship with building section and volume. In the early-tomid-1960s, although plan types varied between those that followed an extended form of architectural promenade, which included external and internal spatial sequencing, the idea of external concealment of programme - and structure - was a theme that characterised some of Gillespie, Kidd \& Coia's centrally planned schemes too (see case studies 1-3).

\section{Theme 3: Section}

Building cross-section is a basic requirement in the communication of an architectural idea, but Gillespie, Kidd \& Coia's churches deal with this in a way that is more fundamental to the experience of their buildings, connecting it to context, scale and liturgical narrative. Related to cross-section are the sub-themes of lighting and structure, as both are either necessary for the creation of, or are created by, the existence of the building's cross-section. Light, as a functional concern, is fundamental to the perception of architectural space and to the architect's lexicon. In the context of ecclesiastical architecture, it is also symbolic, being in almost constant dialogue with a church's liturgical basis. Similarly, structure has a pragmatic aspect as it is reflective of both evolving construction methods and of a response to external parameters such as the economy. It also adopts a phenomenological role when the tectonic aspect of the assembling of structural components is elevated to form a distinct architectural and spiritual experience.

\section{Light}

Historically, the lighting of religious space became fundamentally narrative rather than simply functional; natural lighting in churches being related to the dual effects of the building's crosssectional structure and to the control of spatial experience. In Gillespie, Kidd \& Coia's churches, while always linked to a building's ambience, there is a large degree of variation in light sources. This ranges from the more general lateral-space lighting of the longitudinal churches, such as St Anne's, to experimentally driven directional and diffuse lighting appearing

\footnotetext{
${ }^{49}$ Mark Baines, 'Themes and variations', in Gillespie, Kidd \& Coia, ed. Rodger, 48-69, at 52.
} 
in the late 1930s and extending to the final parish church commission in the late 1970s, frequently from above. In virtually all the firm's churches, the medium of light is treated with immeasurable importance - whether diminished, banished, filtered or concentrated for narrative effect (see case studies $1-3$ ).

\section{Structure}

In addition to the more abstract architectonic considerations of structure, whether hidden, expressed repetitively, or solid and planar - and Gillespie, Kidd \& Coia experimented with all of these constructional choices throughout their practice - an overarching link between structural organisation and the core purpose or parti of ecclesiastical design can be found in its tendency towards directionality or centrality.

One of the most outwardly recognisable traits of Gillespie, Kidd \& Coia's early churches is the degree to which structural logic can be read from external examination. Despite an outward sense of decorum in the lofty main facades of the early churches, which authors such as Watters associate with Glasgow's Beaux-Arts legacy, it is also perhaps the same attribute that lends a certain logic and structural clarity to other aspects of the firm's early work. ${ }^{50}$

Engaging then with Modernism's emphasis on structural and material rationality and 'honesty', immediate post-war churches either appear to investigate holistic structural expression from inside to outside, or else become a more economy-driven model, but still materially honest in their no-frills approach to structure.

Later on, the focus on spiritual journey sometimes separates different structural approaches, with heavy masonry envelopes concealing poetically organised repetitive structure within.

The churches can therefore be organised into those whose main narrative relates to the building's, and hence the liturgy's, sense of direction; and those which are key to its centrality (see case studies 1-3).

\section{Theme 4: Volume - tectonic arrangement and massing}

Volume represents the three-dimensional extrusion of plan and cross-section and is animated by structure and light. On a wider scale, it is linked to a building's setting and its tectonic arrangement and massing on a site. Discounting the attached presbyteries of the first churches, which were not consciously part of the experience of the route into the building, there are three dominant categories of volumetric design. The first considers those churches contained

\footnotetext{
${ }^{50}$ Watters, St Peter's, Cardross, 27-9.
} 
substantially within one volume, the second examines those which physically separated constituent elements of the church into more than one volume, and the third addresses the majority, which consisted of an array of spatial volumes that were physically connected but prominently articulated.

Of the first, St Anne's is linked to some of the later examples, notably Sacred Heart, and St Margaret's. The second consists primarily of St Charles Borromeo and St Bride's, while the third is defined by the long basilican churches with sub-volumes often separated by expressed internal structure, churches that articulate smaller volumes with glazed walkways, and those that are homogenous in plan, but articulated into two distinct volumes in building section.

Hierarchically, a sense of a building's volume is one of the first attributes to allow the observer an impression of its underlying spatial organisation, and of the parts to the whole. It also relates to site and potentially the wider context (see case studies 1-3).

\section{Theme 5: Materials}

Materials relate to construction methods, economic constraints and tectonic possibilities, but also concern aesthetic value and referencing of design details from other sources, particularly when considered in terms of building envelope or internal finish. Except for the Roman Catholic Pavilion, all of the 1930s schemes were executed in brick. The 1930s saw a general increase in the acceptance of brickwork of varying shades and sometimes with contrasting mortar, in church design across numerous denominations. This was perhaps a sign of more contemporary relevance during a period of economic austerity, social and urban change, and progenitor of design language versatility, as Proctor similarly notes in the later example of St. Paul's, Glenrothes. ${ }^{51}$ The entrance elevations to the 1930 s churches employ brickwork in different ways, gradually developing the hierarchically ordered, simplified classical frontage of St. Anne's to plainer, more abstract entrance volumes, remarkable not for their detail but for their material massing.

Although initially following a general inter-war trend for constructional economy and pragmatism, Gillespie, Kidd \& Coia were remarkably consistent in their use of materials such as brick and concrete throughout their decades of practice. The aspect that developed, however, was the visual prominence that they gave to one material over another. For example, at the start, even though St Anne's employed the most up to date steel construction to form the roof, it was entirely hidden by the smooth, curved vaulting of the internal volume, and externally brickwork

\footnotetext{
${ }^{51}$ Proctor, Building the Modern Church, 63-4.
} 
was used to demonstrate the ability of the material to be highly crafted. In the immediate postwar era, the revealing of materials previously thought of as subservient followed general modernist principles of structural pragmatism and 'honesty', while brick continued to be used albeit in a more modest way as structural infill. In the late modern period of the 1960s, certain churches such as St Bride's returned to a wholesale use of structural and facing brickwork in a highly original, monumental way, akin to the stone massing of St. Anna, Düren. In contrast, the final parish church, St Columba's, East Kilbride, reverted to covering up solid, generally featureless external walls with render, first used at the Roman Catholic Pavilion and returned to sporadically over the intervening decades.

A general pattern in Gillespie, Kidd \& Coia churches sees facing brickwork and stone used for the most complex elevational detailing, for example the stereotomy of St Anne's and the low relief of the brickwork of St. Bride's. By contrast, concrete framework is used to legibly demonstrate an interrelationship of structure to internal space and volume, while render describes either external canvas, as at the Roman Catholic Pavilion, or introspection as at Sacred Heart and St Columba's, East Kilbride. Construction material choice necessarily affects other design considerations such as type and placement of apertures, and hence glazing, light, and internal ambience. However, a predominantly brick building did not necessarily mean smaller windows, if, for example, combined with the concrete frame of St Columba's, Woodside. Equally, small, punched geometrical openings were used for the relief of mass brickwork at some of the models of the 1950s. The question of what to do with solid material mass unrelieved by fenestration equally became an interest as the 1960s progressed (see case studies 1-3).

The discussed themes of liturgy, plan, section, light, structure, volume, and materials provide a constant set of parameters that are applicable to all of the ecclesiastical schemes, and are broad enough to permit a wide range of variation in building size, specific function (ie. church, chapel, or oratory), and denomination (ie. Roman Catholic or Lutheran). The following studies are a small number of examples of how these themes were applied to the firm's work.

\section{Case studies}

A student workshop employed a data-gathering and measured survey exercise of a crosssection of ecclesiastical work representative of the entire period of Gillespie, Kidd \& Coia's existence as a practice, which acted as both a check to existing information and provided new information by filling in some gaps in knowledge. Additionally, a novel 3D laser scanning technique was employed through collaboration with specialist surveyors with the aim of 
capturing spatial information from an alternative perspective, and volumetric data that could not otherwise have been recorded.

Six ecclesiastical spaces were surveyed and later the data contributed to inquiry of the themes discussed above [3]. The first study - St. Anne's, Dennistoun - was included because it was the first church commission undertaken by the firm, and therefore the measure for subsequent designs. Its detail, relative to some of the other examples, necessitates a greater proportion of discussion. The second and third represent sub-types within the ecclesiastical category - the former Archbishop's oratory at Park Circus, Glasgow, and the 1950s plain brick volume of the Roman Catholic Chaplaincy within the curtilage of Turnbull Hall, University of Glasgow; the fourth, St. Martin's Church, Castlemilk - represents one of the new parish churches created during the post-war period - a sculptural wedge-shaped structure with attached presbytery; the fifth - St. Margaret's Church in Clydebank, seemingly halfburied in the ground, represents the firm's final commission for the Catholic Church, and by 1972 designed to incorporate the liturgical changes of the Second Vatican Council from the beginning; and the final commission is notable as it not only closes the parish church-building chapter entirely, but was designed for the Lutheran Church - the only example designed for a denomination other than the Catholic Church and the only Lutheran church in Scotland. The following section describes three of these in further detail.

Fig. 3 Workshop case study building comparative plans. St. Anne's, St. Martin's and St. Columba's are described in further detail below.

\section{Case study 1: St Anne's, Dennistoun (1931-33)}

The liturgical character of St Anne's - of the hierarchical staged plan type - corresponds to a developing preoccupation with spatial clarity and analogous congregational engagement while incorporating the heritage and fundamentally axial norms of the Tridentine Mass. Beyond the transitional narthex, entry is into the nave, which culminates axially in a relatively shallow sanctuary ending in an angled apse. The placing of the baptistery at the altar end rather than at the threshold to the church suggests inclusion, and the substitution of conventional side-aisles with arcades serving the confessionals, increases the sense of participation and emphasis on the 
central ritual of the Mass. ${ }^{52}$ This contraction of side-aisles links all of Gillespie, Kidd \& Coia's 1930s churches but this church houses widened zones on each side of the nave serving not as side-aisles but as side-chapels in wide but very shallow transepts with their own longitudinal focus parallel to that of the nave. ${ }^{53}$ St Anne's is a largely homogenous space because its broadness relative to its length, and the low-arched vaulting of the ceiling, consolidate to form a focal point just before the sanctuary [4].
A: baptistery
B: sanctuary
1: zone 1
2: zone 2
3: zone 3

Fig. 4 Single axis layout: St. Anne's, floor plan; and axonometric showing axial layout in relation to Stations of the Cross

The longitudinally planned churches of the 1930s tended to be designed with relatively consistent natural lighting levels, illuminating the nave from the long side walls. At this stage, Gillespie, Kidd \& Coia used two main methods of achieving this; through a single tier of lateral glazing with the use of dormers, as at St. Anne's or by a more traditional basilican model employing low level glazing and separate, higher level clerestorey glazing. Both variations are a function of the cross-section of the building.

Sectionally-driven lighting at St Anne's provides general ambient lighting to the main volume of the building via large, vertically orientated dormer windows. Their rounded heads interact with the descending planes of the mansard roof, with short lateral barrel vaults curving inwards to meet the main barrel vault of the nave. At its lowest point, the roof reaches one storey in height, necessitating shorter windows at this point. Despite the original, unexecuted intention of applying gold leaf to the ceiling, ${ }^{54}$ natural light still has a strong effect on its sense of plasticity. Further lighting effects are created such as the subtle delineation of the groin vault at the intersection of nave and transepts.

\footnotetext{
52 Robertson, 'Tradition \& transition', 17-18.

${ }^{53}$ Ibid.

${ }^{54}$ Neil Baxter, 'Early Coia buildings', in Mac Journal One, eds. James Macaulay and Christian Hermansen (Glasgow, 1994), 16.
} 
While the naves of the early basilican type churches tended to be evenly lit, their sanctuaries, generally shallow and broad, were lit either with glazing within the space itself, or only indirectly from the nave. The sanctuary of St Anne's is expressed as an external projection from the main building volume and the altar is illuminated by oblique side-lighting from two large windows on the angled apse walls [5].

Fig. 5 Building section showing general illumination at St. Anne's

Examples of centralising structure exist across a range of churches, and incorporate both planar and lightweight, repetitive, or framed systems. St Anne's requires discussion in hybrid terms. Although referred to earlier in terms of its axial layout, in the three dimensions of section and volume, the church lies somewhere between directionality and centralisation. This is in part because of the length of its nave relative to its width, the extra width given by the counter-axis of the side chapels, but also to the downward orientation of its barrel-vaulted ceiling which envelopes the entire nave and side chapels. There is effectively a groin-vaulted crossing at the meeting point of the two axes; one of the points of Rudolf Schwarz's idealised altar positions.

As alluded to, St Anne's is a building of some contradiction, and one in which structural legibility is hard to discern. The hierarchical pedimented Italianate front, for example, says nothing of the Romanesque barrel-vault within, itself surprising in the relative lightness of its intersecting dormer windows [1]. Furthermore, beneath the external skin of brickwork, contemporary construction materials such as reinforced concrete and structural steelwork were used, which may have lessened both cost for an Archdiocese needing to keep a very careful eye on its accounts, and expediency at a time of 'material expansion' of the Archdiocese. ${ }^{55}$

Fig. 6 3D laser scan representation of St. Anne's, imaged from below outer roof structure, showing the volume created by the hierarchical interlinking of barrel vaults

Behind the set-piece façade and hidden roof structure, St Anne's is a broadly homogenous volume consisting of a main barrel-vaulted space with a terminal inwardly curving faceted apse and a wide secondary intersecting barrel vault and two further, tertiary pairs of barrel vaults,

\footnotetext{
${ }^{55}$ When Archbishop Donald Mackintosh (1876-1943) began his tenure as Archbishop of Glasgow (1922-43), he engaged in the consolidation of Archdiocesan finances in order to fund the construction of a series of new churches. See Glasgow Herald, 'Obituary Archbishop of Glasgow Most Rev. Donald Mackintosh, D.D.' The Glasgow Herald, $9^{\text {th }}$ December 1943, 2.
} 
also intersecting perpendicularly to the primary vault. The secondary and tertiary vaults are the side chapels and dormer windows respectively. The volumetric arrangement is effective in covering space primarily on - and of - the earth. No campanile or other form of tower offsets this [6].

St. Anne's is a brick-built church surmounting a stone-block plinth, which differed from the previously more common use of stone in ecclesiastical buildings in Glasgow. ${ }^{56}$ Composed of varying architectural inspirations, the principal and side elevations differ from each other, and give limited clues to the interior form and ambience. The church's Italianate front elevation has been well documented, but it is only loosely so inasmuch as the classical motifs employed by Gillespie, Kidd \& Coia are picked out in a paler stone and muted, simplified or stylized. ${ }^{57}$ The west front addresses Whitevale Street in a very particular way that sees a gable end almost transformed into a tympanum, raised slightly above the main body of the nave. The width of the front elevation reduces above the level of the entrance, and simplified scroll brackets reconcile the resultant stepping in of the facade. Rogerson connects these to Santa Maria della Salute in Venice, ${ }^{58}$ but there may equally be a historical precedent in the scrolls that mediate the different widths of the upper and lower volumes of the church at S. Maria Novella, Florence, or perhaps Giacomo della Porta's influential façade of Il Gesù. The referencing of such motifs in Gillespie, Kidd \& Coia's first church establishes a strong re-assertion of Catholicism in Glasgow following the re-establishment of its Archdiocese in 1878; and, more particularly, the installation of Archbishop Mackintosh and Pope Pius XI in 1922. Churches such as Il Gesù became a model for the Catholic Church during the period of the Counter-Reformation. ${ }^{59}$

The tripartite entrance is expressed physically in relief from the brick facade, the top of the arches even being tiled to combat exposure to rain. Again, these are executed in stone, which contrasts to the mellow russet of the long, deeply striated Roman-style bricks. Each of the arched entrances is connected to the next, so that they are read as one entity rather than as three separate openings in the façade; a triptych, in effect. Between this and the gable is a small,

\footnotetext{
${ }^{56}$ Watters, Cardross Seminary: Gillespie, Kidd \& Coia and the Architecture of Postwar Catholicism, 14.

${ }^{57}$ Rogerson, Jack Coia, 18-20.

${ }^{58}$ Ibid., 19.

${ }^{59}$ Watters has suggested that the 'Gesù' similarity existed even before Gillespie, Kidd \& Coia's churches, in those designed by Pugin \& Pugin, but less directly and more in the aesthetic generated by their imposing, assertive presence on the Glasgow skyline. See Watters, Cardross Seminary: Gillespie, Kidd \& Coia and the Architecture of Postwar Catholicism, 14.
} 
centrally positioned oculus window, complete with spokes and central ring, framed with radiating brickwork.

The facade is completed by a pediment - again, detailed in stonework, and broken at the apex with a carved stone figure of Christ, broken also along its horizontal element. ${ }^{60}$ The overall dynamic is horizontal - the relatively long, low, church; the sweeping hipped roof of the presbytery, and emphatic linearity of the brickwork. Yet at points, this is in contention with the strong vertical accents of the dormer windows. The crisp expanses of brickwork with recessed mortar joints take on a sharply orthogonal quality in places, similar to Marcello Piacentini's intensely striated brickwork at Cristo Re, Rome (1924-33), though there, the Italian architect succeeded in creating a regimented bas-relief effect by the slight projection of alternate, three course high bands of brickwork.

\section{Case study 2: St Martin's, Castlemilk (1961)}

The construction of St. Martin's took place in the years immediately preceding the sitting of the Second Vatican Council, so did not respond directly to it, but in its placing of a greater number of seats at the front of the building, and in its resurgence of interest in the sacrament of baptism, it demonstrates an awareness of aspects of the Liturgical Movement. This is echoed in Proctor's noting of Gillespie, Kidd \& Coia's possible access to architectural literary guidance for church designers, ${ }^{61}$ and awareness of Modern architectural ideas linked to the Liturgical Movement, in this case, procession or promenade. Architectural promenade here began with the approach route to the entrance to the church from Ardencraig Road with a terraced ascent across the site. Entrance to the building itself required the visitor to then pass beneath a concrete terraced area via a concealed, darkened transitional zone. Turning into the nave, the space fans out into a wider sanctuary end to the south. Entry is off-centre, just to the east of the central axis, however the fundamental layout is symmetrical. Confessionals here were placed near to the entrance rather than along the side walls of the nave, giving a foretaste of the high theatricality of St Bride's, two years later [7].
A: sanctuary
B: baptistery

\footnotetext{
${ }^{60}$ Rogerson, Jack Coia, 19.

61 Proctor, Churches for a Changing Liturgy, 300-01.
} 
Fig. 7 Architectural promenade at St. Martin's: floor plan; and axonometric showing the dramatic choreography of liturgical ritual and architecture

Dramatic also is the natural lighting at St Martin's, which occurs in those churches whose plans differ from those of the longitudinal basilica. At St Martin's, dramatic lighting is created from a combination of 'punched' wall apertures and repetitive roof lighting [8], [9]. An angled 'wing' flanks each side of the nave, each with oddly sized and placed fenestration. Each lateral wing is roofed with a monopitch, with a diagonally aligned ridge, such that the monopitch becomes deeper as it progresses towards the southern end of the building. At this point, it joins the centrally positioned hemispherical apse, which rises above the level of the nave roof. The two 'wings' frame a central section of roof above the main liturgical space, laid in an almost factory-like configuration of serrated rooflights.

Fig. 8 Photographic section showing the relationship of light to the roof structure of St Martin's

\section{Fig. 9}

Building section showing mixed light sources at St. Martin's

The horizontal bands of glazing are shallowly arched and admit light to the interior; diffuse north light being trained onto the altar. Light is either focused from the glazing between the 'bowstring trusses' above, or else from glazing within the side walls; the apertures being angled within the depth of the wall towards the altar. ${ }^{62}$ St Martin's employs planar structure, which in Gillespie, Kidd \& Coia's churches, was often used in combination with simple masonry piers, and sometimes accentuates the planar massing of walls and ceiling to emphasise massiveness. The first time this approach was used was at St. Columbkille's, appearing again in some of the post-war basilican churches such as St. Martin's, which combines thick, double-skin brick walls - albeit with punched, angled fenestration, with the lightweight roof trusses training light onto the altar.

St Martin's demonstrates, as St Paul's, Glenrothes, a more sculptural approach to the long list of rectilinear 'basilican' layouts that characterise much of the practice's work from its 1930s beginnings to the 1960s. It consists of a gentle wedge-shaped structure with attached but separate presbytery. There is no attempt here to reconcile different elements within the overall

\footnotetext{
${ }^{62}$ Rogerson, Jack Coia,.
} 
outline of the ensemble, as at St Mary of the Angels, Camelon (1960-61); yet the main character in the ensemble - the church itself - behaves quite idiosyncratically in its near symmetry of outline and peculiarity of form [10]. The three-storey presbytery is the first component in a series of three buildings, which together form the church. The eastern volume of the presbytery is flat-roofed and therefore terminates below the adjacent monopitch. This is the constituent that connects to the main church building in a similar manner to that used between the church and campanile, at Holy Family.

At St Martin's, the baptistery is distinct from the church, but fills a gap between it and the presbytery, whereas entry into St Mary's, Bo'ness, was via a glazed porch, which was the element of articulation between the main church building and the baptistery. The baptistery itself was conceived as a small space terminating in a hemispherical wall and topped by a steep monopitch roof. A similarly expressed baptistery exists at St Charles Borromeo.

\section{Fig. 10}

3D laser scan representation of St. Martin's, showing composition of volumetric elements and perforation of the roof by the curved trusses

Currently grey harling masks the original external brick finish with concrete detailing at St Martin's [1], a feature that envelopes the perimeter of the building. ${ }^{63}$ The most notable effect of this covering is its negation of visual impact formerly offered by the more modularised use of concrete and brickwork, the concrete floor slabs expressed externally, with the walls of each storey being constructed in plain brickwork. In this regard, it differs from the playfulness of the brick detailing of St Mary of the Angels, yet it echoes the language of the fenestration there. On the presbytery the brickwork suggests the outlines of the various modules that the glazing assumes. This is treated as floor to ceiling units of varying widths, and apparently arbitrary use of high-level horizontal glazed units that link to another vertical unit. The church is orientated north-south, with the north facade of the presbytery facing the road. The dominant façade is that which draws the visitor towards the hinge-point of house and main church building, and hence the main entrance to the church. The presbytery is given prominence on this side with a sharply monopitched roof clad in green patinated copper panels and is expressed as a volume

\footnotetext{
${ }^{63}$ Johnny Rodger, 'Major works', in Gillespie, Kidd \& Coia, ed. Rodger, 239.
} 
that jetties out beyond the narrow north elevation from first floor level. To the east of the north elevation, a large window, unusually with an arched head cast into the concrete slab, recalls similar construction methods to those used by Le Corbusier at Maisons Jaoul. ${ }^{64}$

\section{Case study 3: St Columba's, East Kilbride (1979)}

Despite the well-documented inherent interest of the churches that followed St Paul's, Glenrothes, relatively little attention has been directed towards the firm's final parish church, designed for the Lutheran Church [1]. St Columba's, East Kilbride is the only example of the practice's ecclesiastical work that was not designed for Roman Catholic worship, and has been included here for comparison. The pulpit, baptismal font, and altar are the key liturgical fixtures of a Lutheran church, ${ }^{65}$ vehicles of the belief in the key theological importance of Scripture, and in the two fundamental sacraments of baptism and the eucharist. ${ }^{66}$ This institution also responded to 20th century liturgical change, particularly in respect of the laity, who became more active in guiding worship. ${ }^{67}$ By the time Gillespie, Kidd \& Coia designed St. Columba's, they had experienced the process of designing a church to meet the revised Roman Catholic missal in the wake of the Second Vatican Council, where the involvement of the laity had been similarly addressed.

St. Columba's emphasises the essential elements of Lutheran worship. It is centralised inasmuch as it houses two arms of seating in an ' $L$ '-shaped arrangement, with the altar, baptismal font and pulpit at their intersection. This particular layout is unique in Gillespie, Kidd \& Coia's work, yet its form of centralisation suggests a variation on their preceding commission, St. Margaret's, with similar orientation of liturgical focus, axis on the diagonal, but with only two banks of seating and more steeply raked: this highly formalised plan commands total focus on the sacramental fixtures, despite its distinctly articulated congregational zones. As an example of one of the firm's partially centralised schemes, the design eschewed architectural promenade, instead combining a congregation strongly linked to the building's liturgical nexus with the straightforward hierarchy of the firm's first axial basilicas [11].

\footnotetext{
${ }^{64}$ Gordon Benson has alluded to influences such as this on Andy MacMillan and Isi Metzstein, in 'Sources, ideas and lessons', in Gillespie, Kidd \& Coia, ed. Rodger, 26-47, at 29.

${ }^{65}$ The Council of Lutheran Churches (no date) Lutheran Worship, online at https://www.lutheran.org.uk/34062/lutheran-worship/ (accessed 17 April 2020).

${ }^{66}$ Alister McGrath, Christian Theology, $6^{\text {th }}$ Ed. (Chichester, 2017), 50-51.

${ }^{67}$ Council of Lutheran Churches, 'Lutheran Worship', Council of Lutheran Churches, online at https://www.lutheran.org.uk/3406-2/lutheran-worship/ (accessed 17 April 2020).
} 


\section{Fig. 11}

St. Columba's, East Kilbride, ground floor plan; and axonometric depicting the nexus of the altar and light tower above

Within the firm's work, top-lit designs and overhead sanctuary lighting created immensely introspective spaces, and here the primary source of natural light enters the building by way of a light chimney elevated above the principal roof level. Sunlight is admitted from the eastern wall of the chimney, casting light onto the rear west-facing sanctuary wall and indirectly lighting the sanctuary. The top lighting emphatically marks its position as the reconciliation of the two wings of tiered seating at 90 degrees to one another [12,13]. An anecdote noting church concern over potential vandalism may have led to a lack of windows, but whether by intention or design, this emphasised the lighting focus on the pivotal point of the layout. ${ }^{68}$

\section{Fig. 12}

Section showing natural lighting at St. Columba's, East Kilbride

Fig. 13 Sectional 3D laser scan image showing lighting at St. Columba's, East Kilbride

Volumetrically, St. Columba's fits into the category of churches whose volumes were physically connected but prominently articulated, a measure that tended to accentuate hierarchical emphasis; here very obviously and dramatically in the light chimney marking the critical meeting of two axes.

Although St Columba's employs a harled masonry structure externally, its levelling effect having been used before at the Roman Catholic Pavilion and even in the white-painted

\footnotetext{
${ }^{68}$ St. Columba Lutheran Church (2014) Lutheran Presence in East Kilbride, online at http://www.scottishlutherans.org.uk/lutheran.html (accessed 17 April 2020).
} 
brickwork of St. Paul's, Glenrothes, internally the building exposes two large and conspicuous castellated steel roof beams, which unify its two 'halves' and direct focus towards the altar. Materially this again references St. Margaret's, whose repetitive lightweight steel roof structure was unique within the firm's oeuvre.

The uniform envelope of external render, coupled with corner light chimney and angled roofline, here achieves a sculptural quality in a final gesture of modest introspection in the closing chapter of the firm's ecclesiastical work.

\section{Conclusion}

This study set out to present examples of a wider exploration in the continuity as well as change in an array of Gillespie, Kidd \& Coia's religious commissions in the context of liturgical transition, by applying experiential and technical filters to building analysis. The methodological approach included a novel mode of data-capture through 3D laser scanning, which revealed a sometimes surprising new perspective on these buildings, particularly in terms of capturing the passage and effects of light, for example, at St Martin's, Castlemilk, and St Columba's, East Kilbride, and in previously hidden graphical volumetric views, for example at St Anne's, Dennistoun.

Despite the quantity of information examined through liturgy, plan, the sectional manifestations of structure and light; volume and materials, what became apparent was the eclecticism of the firm's design approaches.

The practice's inter-war designs continued liturgical traditions but appeared to also extend Coia's own definition of their transitional qualities. ${ }^{69}$ In addition to the stylistic and material aspects of their design, these churches also reflected the more generic Vatican-led recommendations concerning the modelling of internal space to benefit the laity. However, certain also suggested future centralised layouts, for example in the broadness of St Anne's. ${ }^{70}$ The varied plan types reflect a shift in the perceived role of the laity in the liturgy over time, and while still a product of the linear hierarchy of the traditional Latin Mass, the churches designed in the 1930s are situated within the context of a gradual re-thinking of the liturgy. This favoured wider congregational participation and reflected the papal recommendations concerning the reduction of side-aisles, situation of choir galleries to increase visual connection with the altar, reduction of depth and increase in width of the sanctuary. From the 1950s, the

\footnotetext{
69 Jack Coia (1969) 'Royal Gold Medal address', Building, $27^{\text {th }}$ June.

${ }^{70}$ Robertson, 'Tradition \& transition', 18.
} 
alternative positioning of main entrances to otherwise axial layouts began to break away from the traditional plan form into a plurality of approaches, with more didactic inflections, for example in the symbolic 'journey' to and within St Martin's, although the traditional unidirectional seating arrangement was retained here. This phase is characterised by the phenomenological experience of churches as objects, rather than a largely pre-ordained movement sequence up to and through the building, as had been the case earlier. After the Second Vatican Council, more direct focus on the worshipping experience with emphatically introverted spatial programmes emerged. Indeed, external interest is largely minimised in the case of churches such as St Columba's, which although not designed for the Roman Catholic liturgy, eschewed the theatre of previously used architectural promenade, instead combining an inclusively positioned laity with the straightforward hierarchy of the firm's first axial layouts.

Lighting analysis revealed that the first churches relied mostly - but not exclusively - on general lighting of the space itself and not only directed on specific foci, for example the altar. More varied and dramatic conceptions of lighting space arrived in schemes designed after the Second World War and were in part linked to narrative investigations of liturgical sequences through the church. Although undertaken for a different denomination, the last commission relied on the simplest liturgical message: a single source of natural light above the altar.

Overall, structural concepts aligned with the broad groupings of directional or centralising structures, although this did not necessarily always relate to the direction in which seating faced. Articulation of planar surfaces later combined with lighting concepts to produce dramatic internal spaces, evocatively weighty, or intensely focused as at St Columba's, East Kilbride. Centralising structure was either planar or light- weight and tended to reinforce focus on the connection and unity between the congregation and sanctuary.

Single-volume churches, such as St Anne's, tended to relate to centralised structures, and characterise the earliest and some of the later schemes. Those with separately or prominently articulated volumes, however, were often either a product of hierarchical emphasis, or modern theories of architectural experience and discovery through architectural promenade, particular emphases on liturgical arrangement such as the position of the baptistery within the liturgical sequence, or the highlighting of the sanctuary through tower-like volumes, as at St Columba's, East Kilbride.

While Gillespie, Kidd \& Coia's churches initially conformed to more widely used stylistic and material trends, they were acknowledged to have borrowed from an eclectic palette of 
design references. ${ }^{71}$ The reference points for some of the later examples were then openly acknowledged in modernist design terms.

The firm's eclecticism, framed by their prolific design activity over five decades, can be clearly acknowledged; however it is only through close examination of the vast majority of their parish churches, chapels and oratories that enables identification of recurring ideas that speak equally, and perhaps paradoxically, of continuity. Both the firm's historiography and their architectural methods places them within a genuinely international frame of reference.

\footnotetext{
${ }^{71}$ Baxter 'Early Coia Buildings', 18.
} 